
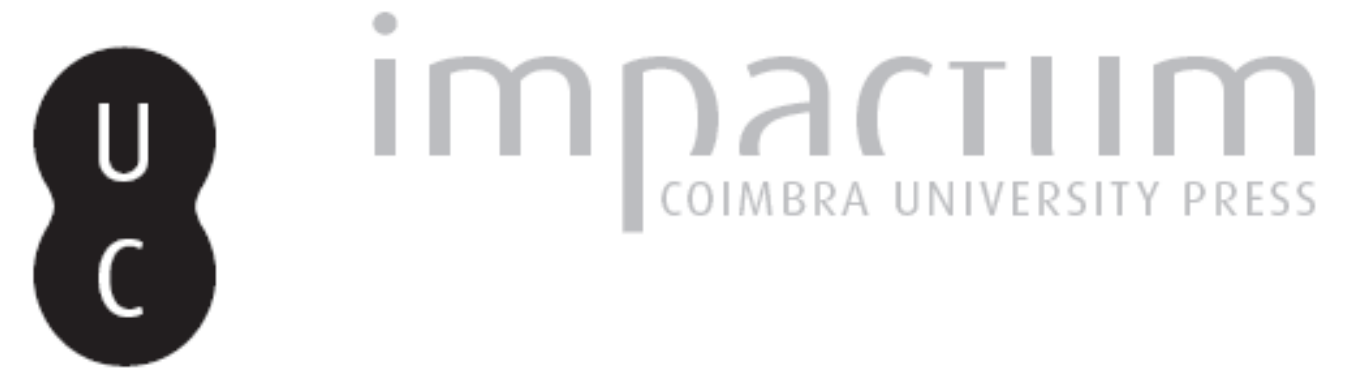

\title{
Propriedade e mérito na teoria da justiça de J. Rawls
}

Autor(es): $\quad$ Neto, João da Cruz Gonçalves

Publicado por: Universidade Católica de Petrópolis

URL persistente:

URI:http://hdl.handle.net/10316.2/33796

DOI:

DOI:http://dx.doi.org/10.14195/2175-0947_3-1_5

Accessed : $\quad$ 26-Apr-2023 13:29:17

A navegação consulta e descarregamento dos títulos inseridos nas Bibliotecas Digitais UC Digitalis, UC Pombalina e UC Impactum, pressupõem a aceitação plena e sem reservas dos Termos e Condições de Uso destas Bibliotecas Digitais, disponíveis em https://digitalis.uc.pt/pt-pt/termos.

Conforme exposto nos referidos Termos e Condições de Uso, o descarregamento de títulos de acesso restrito requer uma licença válida de autorização devendo o utilizador aceder ao(s) documento(s) a partir de um endereço de IP da instituição detentora da supramencionada licença.

Ao utilizador é apenas permitido o descarregamento para uso pessoal, pelo que o emprego do(s) título(s) descarregado(s) para outro fim, designadamente comercial, carece de autorização do respetivo autor ou editor da obra.

Na medida em que todas as obras da UC Digitalis se encontram protegidas pelo Código do Direito de Autor e Direitos Conexos e demais legislação aplicável, toda a cópia, parcial ou total, deste documento, nos casos em que é legalmente admitida, deverá conter ou fazer-se acompanhar por este aviso.

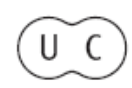



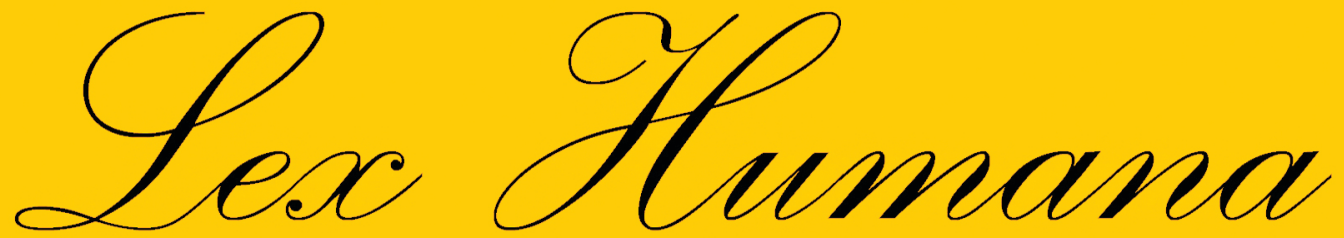

Revista do Programa de Pós-Graduação em Direito da UCP

ISSN(e) 2175-0947

Universidade Católica de Petrópolis Rua Benjamin Constant, 213 - Petrópolis - Centro CEP 25610-130

Tel: (24) 2244-4000 E-mail: lexhumana@ucp.br 


\section{PROPRIEDADE E MÉRITO NA TEORIA DA JUSTIÇA DE \\ J. $R A W L S$}

João da Cruz Gonçalves Neto²

Resumo: Esse artigo visa a apresentar os argumentos de J. Rawls contra o mérito assumido como um critério moral válido e contra a propriedade assumida como um direito individual "puro", em uma sociedade democrática e igualitária. A partir daqueles pressupostos, argumenta que a meritocracia institucionalizada legitima a violência social ao superpor um critério econômico ao critério ético, a eficiência à justiça, bem como subjuga as proteçôes jurídicas destinadas a organizar a sociedade a partir da justiça política, apoiando-se, para tanto, em interpretaçóes restritivas da liberdade individual e da autonomia privada. Diante da reduçáo do político ao moral, conclui que aos direitos humanos cabe a tarefa de assumir-se como teoria da justiça.

Palavras-chave: Propriedade; mérito; violência social; direitos humanos; John Rawls.

Abstract: This paper presents the arguments of John Rawls against the merit assumed as a valid moral criterion and against property assumed as a pure individual right, in a democratic and egalitarian society. From that depart, consider that institutionalized meritocracy endorses social violence when superimposes the economic to ethic criterion, efficiency to justice, as well submits juridical protections to social organization, in restricting interpretation of individual liberty and private autonomy. In the fate of the reduction of the political to the moral, concludes that to human rights is proper to be a general theory of justice.

Keywords: Property; merit; social violence; human rights; John Rawls.

\footnotetext{
${ }^{1}$ Artigo recebido em 26/04/2011 e aprovado para publicação pelo Conselho Editorial em 15/06/2011.

${ }^{2}$ Doutor em Filosofia pela Pontifícia Universidade Católica do Rio Grande do Sul (2006), professor da Universidade Federal de Goiás e coordenador geral da pós-graduaçấo lato sensu da Universidade Federal de Goiás. Currículo Lattes: http://lattes.cnpq.br/6257334752072083. E-mail: dellacroce@dellacroce.pro.br.
} 


\section{Introdução}

Em seu romance $O$ tigre branco, Aravind Adiga (2008) nos provoca um agudo desconforto quando justapóe os ideais de um mundo empresarial de rápida mudança e eficiência, caracterizado pelas cartilhas de motivação pessoal, por modelos administrativos sempre inovadores e por imenso caudal de mensagens de auto-ajuda, ao mundo que ainda náo se economicizou e racionalizou completamente, o da Índia tradicional e pobre. Sob o esmalte da vontade determinada e do mérito pessoal, o discurso empresarial propugna o desejo do indivíduo como dínamo das relaçóes sociais, o auto-interesse como principal definidor da pessoa humana e o compromisso formal (legal, contratual) como único elo coletivo admissível. As normas jurídicas e regulações econômicas garantem a competição normalizada dentro de um mundo pouco previsível, o do mercado, normalização essa sempre reforçada pela propaganda e pelos ideais morais incutidos pela tradição.

O que Adiga faz é indicar que essas normas que regulam as açóes econômicas, funcionam sobre uma base moral inadequada, cujos limites valorativos náo alcançam o que realmente determina as condiçóes do jogo competitivo. Seu personagem, Balram Halwai, o tigre branco, está condenado, como milhóes em muitas geraçóes, a ser pobre e a servir de meio de vida a castas econômicas superiores, num mundo do século XXI. Numa ousada ação "empresarial”, ele assassina seu patráo, toma seu dinheiro (que seria usado para pagamento de suborno a altos funcionários do governo), e monta um lucrativo negócio, mesmo sabendo que, como prática usual em seu país, sua família seria inteira e cruelmente exterminada como pena por seu crime, como de fato o foi. $\mathrm{O}$ argumento implícito do tigre branco (uma raridade entre milhares de outros tigres comuns) é que a competição empresarial, com seus pressupostos morais de confiança, mérito pessoal, ousadia e capacidade de assumir riscos, tem como condição necessária de existência a ação imoral, ilegal, com suas reais forças e motivaçóes fora do discurso público e da propaganda normalizadora. Assim, as regras jurídicas, econômicas, morais e outras regulaçóes competitivas, cerceariam a ação do maior número de pessoas entre limites estreitos, em nome do bem comum, quando o que realmente decide o sucesso individual no jogo está fora desses limites, tal como a situação de um lutador que tem o seu opositor imobilizado sob suas botas enquanto mantém suas mãos completamente livres para agir. A sustentaçáo racional da personagem Balram 
é a de que na luta econômica deve-se aumentar os limites morais para alcançar o que realmente decide o resultado do jogo - o poder, a riqueza, a influência, a oportunidade -, já que nesse jogo a vida e a dignidade individual não são mais que um valor representativo e relativo. Se isso acontece de fato, ou seja, se trazemos para o palco da competição econômica todos os valores que ficam de fora dessa condicionada representação da vida humana (o que significa conceber a sociedade como igualitária e que seus problemas sejam concebidos como racionais e públicos, tais como a modernidade política ocidental a idealizou), teríamos não mais uma moralidade restrita à economia e ao direito, mas avançando na seara da política, o que de forma alguma é admissível pelo discurso economicista ou pela propaganda empresarial. Como é razoável pensar, a pessoa humana pode ser concebida mais amplamente, para além de seu valor funcional e utilitário calcado na noção de mérito individual. O desconforto provocado pelo livro de Adiga, assim, acontece por mostrar que a denúncia do que estrutura a nossa vida comum, os nossos ideais de conquista e de sucesso pessoal, vem com a ação de um assassino frio e egoísta, que rompe uma normalidade não menos violenta e cruel, embora dissimulada. Ele mostra na ação de um indivíduo o que os milhares de condenados à prisão e a infinidade dos casos de patologias psicológicas individuais não conseguem nos fazer ver: que a dinâmica social baseada no mérito individual, no egoísmo produtivo e na eficiência econômica simplesmente não funciona por si só.

\section{A caracterização do mérito individual e a corrupção da subjetividade moderna}

Podemos afirmar que o disseminado senso de justiça baseado no desempenho econômico e moral individual não é um fenômeno novo, pois basta notar que o cristianismo sempre vinculou o comportamento moral do indivíduo à sua salvação espiritual, ao mesmo tempo em que o desligou dos condicionamentos naturais (exceto da "vontade" de Deus), dando-lhe liberdade, autonomia e responsabilidade sobre sua própria vida, naquilo que pode alcançar com seus atos. Novo, entretanto, foi o aterrenamento desses ideais de liberdade, autonomia e igualdade por meio do novo humanismo, trazendo-os da transcendência imaginária para as instituiçóes políticas e jurídicas modernas, a partir de uma nova concepção de realidade e de homem. Essa nova posição retira do que antes tocava a Deus na administração da vida humana e onera 
substancialmente os modelos institucionais de controle de sua história. Se a consciência individual era o único aparato competente para conhecer adequadamente, também sua emancipação dos condicionamentos naturais trará um superdimensionamento de sua força e de sua capacidade de agir, exigindo-lhe um alto preço na organização social, a saber, será feito com que a vontade humana se torne o elemento essencial da organização da vida, e as instituições jurídicas, políticas, morais, econômicas e religiosas se constituirão em torno desta frágil figura idealizada.

Haverá muitas consequências para esse novo mundo organizado sobre nova subjetividade. A busca pela excelência desloca-se do heroísmo individual, quando os deuses ou o Deus cuidavam das determinações heteronômicas, para o heroísmo coletivo, quando o Deus cuida então das proteçóes individuais. Com isso, a necessidade de uma rígida hierarquizaçâo social para se pagar o preço de investimentos em áreas de vanguarda tecnológica, estilo, poder, exibicionismo ou em outras experiências humanas sofisticadas, se fará não mais se invocando a natureza sobre ou contra a vontade do individuo, mas se invocando a natureza na vontade do indivíduo, que é o mérito moral contido na vontade fortemente determinada à adaptação e à normalidade. Debaixo do iluminado imaginário moderno da liberdade, igualdade e democracia, milhões de pessoas sucumbiram em nome dos ideais com suas realizações sempre postergadas, das grandes conquistas coletivas, das engenhosas maravilhas que enriqueceram as fantasias, mas não necessariamente a vida. $\mathrm{O}$ que restava fora dos ideais atrativos e significantes, havia-se que aniquilar em si, psicológica, física, social, jurídica, econômica ou moralmente, havendo a religiáo para ligar as duas pontas da mutilação justificada racionalmente.

Outra conseqüência da nova subjetividade discursiva moderna foi ter o problema humano reduzido à estrutura da moral individual. Os problemas coletivos e as opçóes políticas tenderam a ser compreendidos pelo viés do interesse pessoal, e muito da complexidade da realidade social não pode ser percebida nem em temos de escolhas morais, nem em termos de eleiçóes sobre postulações binárias, decididas por maioria. Muito do material de formação do imaginário público, como um imaginário comum aos indivíduos, é feito de emotivizações confusas de acontecimentos percebidos como pessoais ou não percebidos. Com isso, a régua moral, vinculada a essa percepção emotivizada da realidade, restringe o alcance da consciência individual, que se vê em um palco com todas as regras necessárias à vida e ao relacionamento já dadas. Assim, o direito seria a expressão do certo e do justo; a religião a expressão da verdade; a moral do necessário nas 
relaçôes; a política a expressão apenas da administração. Náo haveria aí o espaço para o que realmente decide a dinâmica da vida social, com suas relaçóes de poder e seus ideais dissimuladores. Dentro do alcance da visão moral do indivíduo, cabe um continente de problemas e realidades mais limitadas que o necessário para se compreender a dinâmica social, para além de sua idealização. O desafio político por excelência é aumentar o conteúdo semântico desse intervalo valorativo, desligando-o de práticas discursivas redutoras. Isso significa restaurar o espaço da política, desnaturalizando a vida social, tal como sonharam os Iluministas.

Uma interessante abordagem do mérito moral, no interior de uma elaborada teoria da justiça que tenta resignificar os ideais políticos do Esclarecimento é a que é feita na obra de John Rawls, pensador americano contemporâneo que constrói uma teoria da justiça submetendo o econômico ao político, e o político à moral, de uma maneira inédita na tradição liberal.

3. O mérito individual na teoria da justiça de J. Rawls

A abordagem de Rawls sobre o mérito moral, dentro da tradição liberal, é uma subversão. Isso porque o essencial de sua teoria da justiça é conceber o papel moral do sujeito, tanto quanto sua configuração epistêmica, a partir de um ponto de vista socializado, no qual a consciência individual é antecipada por condiçôes heterônomas que condicionam a sua liberdade. Dentro de uma tradição liberal-cristá, que erigiu as suas instituiçóes econômicas, jurídicas, morais, religiosas e políticas sobre a vontade humana pretensamente livre, essa é uma idéia que se soma à corrente tradicionalmente reputada às esquerdas políticas, de Hegel em diante, que ainda não encontrou guarida prática em nossas instituiçóes e no nosso modo de vida comum. Cremos, entretanto, que os próximos anos deverão exigir um remodelamento da concepção do sujeito, na sua aplicação prática, pelos dilemas que a racionalidade vigente já não consegue responder. $\mathrm{O}$ modelo oferecido pela justiça como equidade é uma ponte teórica bastante interessante para uma nova representação pública dos problemas morais contemporâneos.

"O senso comum tende a supor que a renda e a riqueza, assim como as boas coisas da vida em geral, deveriam ser distribuídas de acordo com o mérito moral. A justiça é a felicidade de acordo com a virtude" (RAWLS, 1997, p. 342). Esse é notadamente um senso de justiça 
profundamente partilhado em nossa cultura, que também se vê como competitiva, com meios de vida escassos, na qual indivíduos cujas consciências se antecipam à realidade podem se compreender no mundo e podem deliberar livremente, por conta de sua incolumidade epistêmica, tanto sobre sua vida privada (moralmente) quanto sobre a vida pública (politicamente). Embora esse senso de justiça meritocrático seja naturalizado em nossa cultura, a dificuldade em sustentá-lo a partir dos demais fundamentos de nosso ideário político e moral é flagrante. Tal confronto expóe contradições entre a representação de indivíduo e de interesse público, quando fomentados pelos ideais de justiça democráticos e igualitários, ideais que também formam nossa representação pública em sua intimidade. Rawls expóe alguns motivos pelos quais não podemos admitir o mérito moral como um critério legítimo de distribuiçáo de bens e riquezas em nossa sociedade democrática, quando temos um critério de justiça igualitário, que, aliás, só aparentemente fomenta a perspectiva meritocrática.

O primeiro motivo é que a idéia de distribuição de acordo com a virtude não consegue distinguir entre mérito moral e expectativas legítimas (RAWLS, 1997, p. 343). Expectativas legítimas são aquelas geradas por um sistema de reivindicaçóes mútuas definidas por regras publicamente reconhecidas. As pessoas que participam de organizaçóes justas e realizam certas açôes incentivadas por elas, possuem direitos, expectativas legítimas, que não dependem do valor intrínseco delas. Evidentemente que o direito do indivíduo sobre a sua parte na distribuição da riqueza náo depende de suas qualidades naturais, ou talentos raros. Por exemplo, se o futebol, por algum motivo, deixar subitamente de ser popular no mundo e com isso deixar de ser um negócio milionário, a fortuna de Cristiano Ronaldo pode diminuir substancialmente e ele não ser mais reconhecido nas ruas, embora a sua habilidade como jogador continue a mesma. Em uma sociedade justa, portanto, não se pode ter como critério de distribuição de riquezas o mérito moral, mas sim um sistema de expectativas legítimas. Obviamente, o valor da pessoa, numa sociedade que se vê como igualitária, não pode se basear na loteria genética ou mesmo na sorte; seu valor "natural" deve repousar em algo anterior à conveniência econômica, à utilidade pública, à excelência humana, às leis de mercado, a saber, numa definição jurídica derivada de amplo pacto social que garanta direitos de igual proteção e usufruto dos bens que apenas socialmente poderiam ser produzidos. 
Outro obstáculo racional à consideraçấo do critério do mérito, além da dificuldade de sua própria definição, é a percepção de que o desempenho moral está ligado às habilidades naturais do indivíduo. Essas habilidades são arbitrárias, distribuídas ao acaso, e a assunção de uma certa concepção de naturalidade como a seleçáo natural espontânea que deva ser protegida pelas instituições parece estar fora de questáo, felizmente. As nossas instituições não devem seguir a luta pela sobrevivência pelo critério da força, como se a própria existência de um ser dependesse da destruição do outro, e assim justificar a desigualdade econômica e moral. A concepção da pessoa como determinada e determinante das relaçóes sociais impede que consideremos o sujeito epistêmico como inteiramente responsável por condiçóes heterônomas, e mesmo como inteiramente responsável por sua consciência moral. Assim, se intuitivamente o critério que melhor se aproxima do mérito moral é o do esforço, ou seja, o de que a distribuição deve ser feita de acordo com o esforço contencioso, está claro que o esforço que uma pessoa está disposta a fazer é influenciado por suas habilidades e talentos naturais, bem como pelas alternativas que ela dispóe (RAWLS, 1997, p. 344). Não é viável, mais uma vez, a idéia de se recompensar o mérito moral.

O fato de que o mérito moral não possa ser introduzido antes de se reconhecer os princípios de justiça que regularão a vida social, o dever e as obrigaçóes naturais, é outro argumento a desabilitar tal critério como um princípio básico da justiça distributiva. A justiça como equidade vê na deliberação e âmbito políticos a necessária consideração universal e pública dos interesses individuais, que condiciona heteronomamente as vontades e interesses particulares, antecipando a justiça às demais consideraçóes morais. Como uma ruptura de certo liberalismo dominante na tradição americana, isso significa fazer com que as instâncias jurídica e moral se submetam à instância política; na instância moral, significa submeter os valores morais (individuais) à justiça, ao mesmo tempo em que submete a política, e o interesse público, à proteção ao indivíduo universalmente considerado. Esse individuo abstrata e universalmente considerado é a reserva institucionalizada dos direitos humanos. Rawls afirma que é táo implausível que uma sociedade se organize para recompensar o mérito moral quanto uma sociedade criar a instituição da propriedade para punir ladróes (RAWLS, 1997. p. 345). Nesse sentido, o mérito moral é uma decorrência de arranjos prévios e justos, e não o contrário, assim como a virtude pode ser definida como desejos e tendências a agir de acordo com os princípios correspondentes. 
Deve-se atentar ao fato, ainda, de que a justiça distributiva não é oposta à justiça retributiva, no âmbito de uma sociedade democrática igualitária. Isso equivale a dizer que os interesses privados, em geral, náo se confrontam com o interesse público, dentro de certas circunstâncias. Essa idéia não é aceita facilmente sem compreendermos as condiçôes estabelecidas por sua Teoria. Uma dessas condiçóes é a de assumir a sociedade como um sistema cooperativo que visa ao bem estar de todos, que usa a competição entre os indivíduos para o benefício de todos, e não apenas para o benefício pessoal do afortunado ou do mais dotado de talentos naturais. Outra condição é a de se imaginar o indivíduo como necessariamente social. Não há uma possibilidade para a vida humana, um lado de fora, uma situaçáo de estado de natureza que nos permita ver o indivíduo como epistemicamente isolado, cuja consciência julga a vida social a partir do próprio interesse. Vivemos em um mundo fechado, do qual não há saída, exceto na mudança racionalizada e institucionalizada em termos públicos e universais. A consciência individual é também determinada pelas condições sociais, e os valores que se perseguirão possuem apenas sentido coletivo. Assim, em uma passagem bastante polêmica, Rawls afirma que os dotes naturais não pertencem ao indivíduo, e que os princípios de justiça adotados por partes imaginárias em condiçóes ideais apenas permitiriam as desigualdades econômicas no interesse de todos, o que faz com que não haja apropriação pessoal do que apenas recebeu valor pela coletividade. Eis uma passagem esclarecedora:

Os dois princípios aludidos (de justiça) parecem constituir uma base equitativa sobre a qual os mais dotados, ou os mais afortunados por sua posição social, duas coisas de que não podemos ser considerados merecedores, poderiam esperar a cooperação voluntária dos outros quando algum sistema viável fosse uma condição necessária para o bem-estar de todos. Uma vez que decidimos buscar uma concepçáo da justiça que impeça a utilização dos acidentes da dotação natural e das contingências de circunstâncias sociais como trunfos na demanda de vantagens econômicas e políticas, somos levados a usar esses princípios. Eles expressam a conseqüência do fato de deixarmos de lado aqueles aspectos do mundo social que parecem arbitrários de um ponto de vista moral. (RAWLS, 1997, pp. 16-7)

As partes distributivas desiguais, então, só se justificam de uma maneira - que elas sirvam para o maior bem coletivo. É para “... cobrir os custos da especialização e educação, atrair indivíduos aos lugares e associaçôes que, de um ponto de vista social, mais necessitam deles, e 
assim por diante" (RAWLS, 1997, p. 348). A competição entre indivíduos passa a ser violência institucionalizada quando não está orientada para o progresso coletivo, e quando não expressa a liberdade coletiva de ter condiçóes heterônomas iguais. A moralidade não tem sentido algum sem essa igualdade de condiçôes, que somente pela ação política pode ser conseguida. Sem uma estrutura social justa, a moral é apenas um instrumento de exclusão, tal como as reservas de propriedade, as práticas religiosas e todas as instituições que se constituem sobre a adesão voluntária como instrumento de proteçáo, em um mundo injusto e violento que precisa da anormalidade ou da recusa para excluir e destruir. Os direitos humanos, assim, tornam-se importantes instrumentos jurídicos e morais de proteção social enquanto não temos uma justiça política como mediadora de nossas instituiçóes, assim como a distância entre nossos ideais de igualdade e seus discursos legitimadores não estejam tão distantes um do outro.

Podemos assim resumir os argumentos contidos na Teoria da justiça contra o mérito moral como um critério de justiça válido, por mais arraigado que esteja em nosso senso comum:

- A organização social deve estabelecer-se a partir de uma racionalidade construída sobre os condicionamentos democráticos e igualitários.

- As desigualdades econômicas são aceitas apenas se existirem em benefício da coletividade. Por exemplo, um salário maior para talentos raros é apenas admissível se for para cobrir os custos da especialização ou atrair esses talentos para funçóes que melhorem a vida da coletividade. $\mathrm{O}$ indivíduo não possui um direito natural sobre o próprio talento.

- $\quad$ O mérito moral é difícil de ser definido e identificado. Numa perspectiva contratualista, é mais razoável falar de expectativas legítimas, que são derivadas de um sistema de direitos elaborados a partir de um fórum universal, democrático e igualitário.

- A Teoria da justiça vê na moralidade a esfera da liberdade do indivíduo, mas vê na política a determinação das condiçóes sobre as quais essa liberdade se define. Sua concepção de pessoa prevê essas determinações sociais, e sobre elas sobrepõe os princípios de justiça. Assim, não se pode falar de uma liberdade tomada em termos meramente morais, como se as relações morais sozinhas fossem 
suficientes para realizá-la. É preciso falar de liberdade política, numa perspectiva que compreende a ação individual a partir dos valores fundantes de nossos ideais mais profundos, de racionalidade, razoabilidade, igualdade, publicidade, universalidade e cooperação social, ao invés da competição regulamentada desde as desigualdades históricas.

4. Uma concepção mais complexa de pessoa

No mesmo mundo no qual indivíduos competitivos usam de sua liberdade e disciplina para criar vantagens pessoais frente aos interesses concorrentes, contra uma riqueza limitada e universalmente produzida, temos a propriedade privada como o principal repositório de segurança individual. Diante das condições tradicionalmente pensadas no imaginário liberal, de que a vontade humana é efetiva na moral, mas não necessariamente na política, e que, portanto, as condições de segurança social são utópicas demais para serem realizadas, a propriedade privada se mostra como a melhor forma de proteção e estabilidade num mundo onde tudo o que nos é valoroso depende do precário e incerto confronto das vontades livres.

Evidentemente que um critério de justiça social que pretenda limitar os resultados da dinâmica econômica aos princípios distributivos que considerem todos os interesses igualmente, não admitirá o mérito como vantagem competitiva natural, assim como não aceitará a propriedade privada como um direito que se antecipe à conveniência social. Ou seja, apenas uma teoria social que compreenda a pessoa humana como uma consciência desligada e anterior às determinaçôes sociais é que poderá assumir a liberdade individual como ameaçada pelo interesse público, ou que haja um real confronto entre a liberdade e a igualdade. Exemplo desse modelo é a teoria de Robert Nozick (NOZICK, 1994).

A teoria social de Rawls está implícita numa idealização de condições ótimas de vida pública, de forma a mostrar que essas condições se assentam numa representação realista de nossa tradição liberal - e isso é o que ele chamará posteriormente de utopia realista. Nessa idealização, a noção de pessoa está ligada a todo o artifício teórico, e é instrumental e simples, isto é, os indivíduos são "tomados como pessoas éticas, como seres racionais com objetivos próprios e capazes de um senso de justiça” (RAWLS, 1997, p.13). Por si só, evidentemente, essa definição 
não mudaria nada da concepção tradicional do liberalismo (e do cristianismo) de uma consciência livre lançada ao mundo depois dele constituído. Entretanto, o seu modelo da justice as fairness complementa essa noção, tornando-a mais complexa quando insere as consciências individuais em condiçôes de pensamento e deliberação que levam em conta o conjunto dos interesses e a universalidade das pessoas assim consideradas, replicando com isso as condiçóes de uma teoria social mais elaborada, que leva em conta a formaçáo do sujeito epistêmico pela vida da cultura e pela práxis. Essa é a função da chamada posiçâo original, na qual as partes (indivíduos) podem deliberar sob condiçóes livres dos particularismos, da conveniência imediata e das pressões do poder estabelecido, e identificar o interesse privado ao público, o imediato ao histórico-cultural. É esse o complemento que, sem o qual, não se compreende adequadamente as noçôes de pessoa e de sociedade no modelo em questáo.

A opção pelo individualismo metodológico é puramente contingencial, por estar ligado historicamente à nossa tradição liberal democrática. Eis como o autor se pronuncia:

A ideia essencial é que queremos explicar os valores sociais, o caráter intrinsecamente bom das atividades institucionais comunitárias e associativas, através de uma concepção da justiça que, em sua base teórica, é individualista. Por motivos de clareza, entre outros, não queremos ter por base um conceito indefinido de comunidade, ou supor que a sociedade é um todo orgânico com vida própria e distinta da vida de todos os seus membros em suas inter-relaçôes. (RAWLS, 1997, p. 297)

E ainda:

Como já vimos, a decisão quanto ao melhor sistema para um determinado povo depende das circunstâncias, instituiçôes e tradiçôes históricas desse povo. (RAWLS, 1997, p. 310)

Temos, assim, uma concepção individualista de sociedade que se situa no interior de condiçôes sociais definidas pelo interesse público. Em outras palavras, a heteronomia ao mesmo tempo em que condiciona a autonomia, também está submetida a essa mesma autonomia.

Essa noção de pessoa nos faz compreender melhor o quão o mérito pessoal náo pode ser um critério válido de justiça, da mesma maneira como a propriedade náo pode ser assunto concernente apenas à liberdade individual. 


\section{Propriedade e mérito}

Para aplicar-se qualquer noçáo de justiça à estrutura da sociedade, é preciso que haja um poder social organizado em instituiçôes sólidas, e necessariamente de caráter interventor nas vontades e interesses individuais, em nossa cultura, por meio de um Estado. A assunçáo da sociedade como não orgânica, mas tomada em sua totalidade, impóe a necessidade de se condicionar as vontades (liberdades) individuais às possibilidades públicas universais, o que, no interior de uma vida social razoavelmente justa, torna-se um problema menor. Assim é que, numa sociedade de mercado, a apropriaçáo do que quer que seja, dos próprios talentos, de direitos, objetos ou vantagens morais (tal como a auto-estima competitiva), não pode ser considerada por si mesma, com um ato isolado, sem consideraçáo sistêmica do que forma o próprio interesse que deve ser protegido pela liberdade. Esse interesse, tal como deve ser protegido, é também produzido por condiçóes que não estão submetidas às deliberações individuais. Afinal, como podemos conferir uma liberdade individual ilimitada quando as próprias condiçóes que produzem os interesses não são produzidos por essa liberdade?

Toda teoria da justiça é um apelo pela volta da grande política, enfim, pelo desejo de ter novamente os interesses públicos geridos não pelo oportunismo ou pelas desigualdades históricas, mas pela consideração do público submetido ao ideal da razão pública.

É assim que Rawls pensará na escolha de um sistema social que seja pautado pela justiça distributiva. Para tanto, "é necessário situar o processo econômico e social dentro de um contexto de instituiçóes políticas e jurídicas adequadas". (RAWLS, 1997, p.303) Essas instituiçóes de apoio são uma constituição justa que assegura as liberdades de cidadania igual; a liberdade de consciência e de pensamento; o processo político conduzido para a escolha do tipo de governo e para a elaboração de uma legislação justa; a igualdade de oportunidades; o governo garantidor de um mínimo social. Essas instituições são pensadas no interior de um estado democrático organizado que permite a propriedade privada de capital e de recursos naturais. (RAWLS, 1997, p. 303-4)

No estabelecimento dessas instituiçóes básicas, o governo se divide em quatro setores: o setor de alocação, que serve para manter a competitividade do sistema de preços e proteger o mercado; o setor de estabilizaçâo, que luta para criar um sistema de pleno emprego razoável. O 
objetivo desses dois setores é manter a eficiência da economia de mercado. Há ainda o setor de transferência, que tem por responsabilidade manter o mínimo social e, finalmente, o setor de distribuição, cuja tarefa é preservar uma justiça aproximativa das partes a serem distribuídas por meio de taxação e dos ajustes no direito de propriedade que se fazem necessários. (RAWLS, 1997, p. 305-6)

Fica bastante claro o papel do Estado quando se pressupóe a economia submetida à política, e a liberdade individual submetida à liberdade social. O estado é forte distribuidor da riqueza produzida socialmente e essa riqueza é tomada em seu aspecto global, o que implica considerar o valor econômico e o valor moral como só dotados de sentido no interior de um sistema convencional valorativo e histórico. É nesse mesmo sentido que Nagel, inspirado por Rawls, afirma que

A propriedade privada é uma convenção jurídica definida em parte pelo sistema tributário; logo, o sistema tributário não pode ser avaliado segundo seus efeitos sobre a propriedade privada, concebida como algo dotado de existência e validade independentes. Os impostos têm de ser avaliados como um elemento do sistema geral de direitos de propriedade que eles mesmos ajudam a criar. (NAGEL, 2005, p.11)

Notamos que esse papel distributivo do Estado compreende os direitos de propriedade como objetos de decisão política no sentido de se buscar uma estrutura básica justa. A feição contratual de sua teoria não considera qualquer valor como dotado de justificativa pré-social. A função social da propriedade, neste contexto, não é apenas a garantia do direito sagrado à propriedade sob a condiçáa de torná-la produtiva economicamente; é fazê-la objeto de intervenção social legitimada por todas aquelas instituições de apoio elencadas anteriormente (o mínimo econômico, a igualdade de oportunidades, a desigualdade que não se justifique pela melhoria global, pelo desequilíbrio no exercício do poder, entre outras). Sendo a propriedade o maior fator de segurança social, ainda mais para países como o Brasil, onde a desigualdade econômica produz um clima de guerra social, e onde as instituiçóes públicas não são suficientemente maduras e não propiciam segurança jurídica e política adequadas, essas afirmaçóes soam com um ataque semelhante aos piores pesadelos comunistas imaginados por nossos passados regimes ditatoriais de direita. 
Com sua teoria Rawls, sem menção, ataca o chamado fetichismo institucional e estrutural, nome dado por Mangabeira Unger à distinção feita por algumas teorias sociais entre os contextos formadores e as rotinas formadas, e que classificam o contexto formador sob um tipo reproduzível e indivisível. (UNGER, CUI, 2001, p. 13) É assim que é possível conceber uma sociedade de mercado estabelecida numa democracia de proprietários, mas não reconhecer como dotados de autonomia e independência os efeitos de determinado arranjo institucional. Se historicamente as democracias constitucionais liberais nascem com as economias de mercado e os sistemas de direitos privados semelhantes aos atualmente vigentes, não quer dizer que essas características sejam reproduzíveis sempre da mesma maneira, e que não possam ser alterados com independência umas das outras.

Assumindo, dessa maneira, que os interesses devem ser considerados universalmente (para todos os humanos indistintamente), e quando assim são, há a necessidade de instituiçôes que controlem as condiçóes a partir das quais a liberdade individual deverá operar, compreendemos melhor as noçóes contra-intuitivas expostas pela teoria da qual fazemos uso. Como temos apresentado, essas noçôes são duas: da propriedade tomada como convenção e como função social (no sentido acima explicitado), que deve primeiro respeitar ao interesse público; e da relação não proprietária dos talentos pessoais com sua função social.

Pela falta de maturidade política, nossa cultura ainda não possui instituiçôes que protejam os indivíduos de uma guerra competitiva com imenso desperdício de energia social, até que o mundo inteiro esteja integrado num mesmo sistema de igual consideraçáo e direito. Assim, é facilmente perceptível que a mediação proprietária torne-se, pelo menos na aparência, a principal arma de defesa privada. É intuitivo, pois, pensar em todas as nossas relaçôes, em todos os níveis, como relações proprietárias, seja na economia, na afeição, na religiosidade e até nas representações de subjetividade, com eus que possuem o "próprio" corpo e as "próprias" características psicológicas. Como dito antes, não é o caso de razoavelmente desejar uma mudança radical e histórica na representaçáo de mundo das pessoas a partir de mudanças políticas. O século XX foi um palco em demasia trágico nas suas representaçóes de vida boa, correção e verdade. Outra coisa, entretanto, é desejar no interior do próprio quadro cultural uma mudança que faça a transição da segurança privada das pessoas para a segurança pública. 
É nesse contexto que o mérito pessoal, numa sociedade de competidores e em meio a recursos escassos, torna-se uma vantagem do indivíduo no interior de um sistema moral, econômico e político que coloca as pessoas umas contra as outras, mesmo quando a competiçáo foi pensada classicamente para ser travada entre empresários e capitalistas, e não entre indivíduos.

Os dotes naturais, assim, não podem ser vistos como propriedade privada, que embora possam ser usados (praticados) de forma livre, não podem ser usados como fatores exclusivos de exploração econômica. Assim diz Rawls:

Não merecemos nosso lugar inicial de partida na sociedade. Também é problemática a questáo de saber se merecemos o caráter superior que os possibilita fazer o esforço de cultivar nossas habilidades; pois esse caráter depende em grande parte de circunstâncias familiares e sociais felizes no início da vida, às quais não podemos alegar que temos direito. A noção de mérito não se aplica aqui. (RAWLS, 1997, p. 111)

A natureza contratualista da teoria social de Rawls vai bastante além do que se costuma esperar de teorias equivalentes. Nela, a subjetividade também é convencional, depende das condições sociais para se estabelecer. Por isso, não pode ter suas características definidas como propriedade. E mesmo que fossem, o seu valor econômico depende diretamente de seu valor social, do que é produzido socialmente, e não pode, portanto, pretender uma incolumidade econômica num sistema de valores mutuamente construído. Em outras palavras, não é justo se apropriar de talentos e habilidades produzidos pela cultura e dispostos aos indivíduos de acordo com suas características, ao longo do tempo, e privatizando-se apenas os lucros, principalmente quando pensamos na riqueza social como produzida por uma infinidade de talentos entrelaçados, necessários e interdependentes.

\section{Conclusão}

Cremos ter esclarecido as noçóes de mérito pessoal e propriedade na teoria da justiça de John Rawls, mostrando a mútua dependência desses conceitos e o quão sua inserção numa teoria igualitária os estabelece em contra-senso das teorias e práticas liberais correntes em nossa atualidade. 
Essa abordagem é tanto mais oportuna quanto mais se deve evidenciar o cinismo do discurso meritocrático, do triunfo pessoal, que com tanta força penetrou nos discursos economicistas, jornalísticos e empresariais. Nesse discurso, toda a teoria social necessária à prosperidade social é a que leva em consideração e desenvolve as instituiçóes para reconhecer e privilegiar os talentos individuais. Os resultados de tais práticas e propaganda começamos a ver pelos índices sociais, principalmente médicos ${ }^{3}$, nos quais náo se distinguem os vencedores dos perdedores econômicos. Nada soa mais falso que os artifícios políticos, administrativos e publicitários para fabricar os heróis e os símbolos da prosperidade. Não que não haja grandes talentos, ou que seu incentivo não seja importante à prosperidade comum; o uso dos talentos para justificar grandes desigualdades econômicas é que não parece razoável.

O incentivo à competição entre os indivíduos promoveu, nos últimos trinta anos, e por si só, a responsabilização individual por seu desempenho econômico. Citando Ulrich Beck (BECK, 1992), tem-se procurado soluçóes biográficas para contradiçôes sistêmicas. Muito disso tem se apoiado em noções levianamente ingênuas sobre as relaçóes entre moral e política, afastando-se essa última da possibilidade de ação. Não há melhor maneira de desvelar essas ideias latentes que expor a impropriedade das noçôes de mérito e propriedade sem levar em conta a abordagem política (e da justiça) de nossa dinâmica social.

Essas ideias não podem ser inteiramente esclarecidas sem a consideração apropriada da noção de pessoa em nossa teoria social. Como afirmamos anteriormente, o espaço do indivíduo não se resume ao espaço de proteção jurídica do humano. A reserva humana que define o sujeito de direito deve levar em conta o interesse público como a capacidade de gerir a própria vida social na história, e não somente a proteçáo dos interesses de grupos e coletividades com novas titularidades. A complexidade do real deve se soltar do discurso que o compreende, bem como da régua valorativa que reduz o público ao privado, e isso implica em não reduzir os problemas de ordem política a problemas de ordem moral. O critério que elege o mérito moral como princípio de justiça tenta fazer o inverso ao considerar a liberdade individual como a de um sujeito epistêmico pré-existente às condições sociais, como se fosse uma consciência metafísica lançada ao

\footnotetext{
${ }^{3}$ Os índices de suicídio nas sociedades competitivas, pouco divulgados, e mesmo a grande incidência das doenças de nossa época, tais como a depressão, a ansiedade, a baixa-estima, a síndrome do pânico, a hiperatividade, entre outras, dizem mais sobre nossas relaçóes sociais do que a racionalizaçáo de nossa vida a partir dos ideais econômicos, morais ou políticos que orientam nossos sentidos públicos de ação. 
mundo. É assim que a luta por direitos pode se constituir em violência e a mais correta moralidade ser extremamente injusta.

Em condições de justiça social razoável, ousamos dizer que a desigualdade econômica não agride moralmente a pessoa, ou mesmo outra forma de desigualdade para a qual não há remédio. A desigualdade realmente massacra quando se pretende, ostensivamente, induzir a pensar que todos podem ser iguais em todos os aspectos, que os potenciais individuais não são complementares, que todos possuem potenciais ilimitados, em todos os aspectos e acessíveis ao consumo, e que é somente uma questão de esforço pessoal atingi-los. Temos visto isso nos últimos anos, seja pela maior democratizaçáo, pela inserçáo de maior número de pessoas no mercado de consumo, e por conseqüência, no mercado de sonhos consumíveis, bem como pelo fabuloso desenvolvimento tecnológico motivado por esse consumo, incentivando a motivação pessoal a experiências que dificilmente podem ser garantidas no nível prometido. Nesse mundo, não há meio termo confortável: ou se é um herói simbólico, o qual tem a opção de acreditar em si mesmo e no mercado de personalidades, ou se é um perdedor ontologicamente considerado, um nada, um fraco, ou qualquer coisa bastante negativa. Pertencer a um grupo, ser aceito e respeitado por esse grupo, é satisfação mais primária que elevar padrôes de consumo. O sofrimento psicológico de origem moral foi bastante inoculado nos últimos anos, estimulando-se, pela publicidade e pelo jornalismo, o culto da ambição, do herói, do triunfo pessoal, da competição acelerada, de um lado, e, de outro, a diminuição da importância do trabalho em equipe, dos esforços coletivos, da felicidade simples, da importância dos que não estão imediatamente visíveis. Tudo o que o senso comum liberal já tinha por acordo tácito antes da disparada competitiva, acelerada desde os anos 80.

Repensar os modelos de desenvolvimento econômico é um imperativo de ordem política, que se tornará mais urgente quando entre as vítimas estiverem também os tradicionais vencedores. Para o ataque estrutural e seus efeitos não se encontrará proteção na ordem jurídica, nem tampouco nas lutas por reconhecimento. O discurso dos direitos humanos só ousará tocar o problema central quando, além de ser apenas um discurso estratégico e moralista, for também um discurso político global, e integrar um discurso maior sobre a justiça social. 
Referência Bibliográfica

ADIGA, Aravind. O tigre branco. Rio de Janeiro: Nova Fronteira, 2008.

BARBOSA, Lívia. Igualdade e meritocracia. Rio de Janeiro: Fundação Getúlio Vargas, 1999.

BAUMAN, Zygmunt. Vidas desperdiçadas. Rio de Janeiro: Jorge Zahar, 2005.

BECK, Ulrich. Risk Society. Londres: Sage, 1992.

CUI, Zhiyuan. Prefácio à Política, de Roberto Mangabeira Unger. Sáo Paulo: Boitempo; Santa Catarina: Argos, 2001.

FOUCAULT, Michel. Vigiar e punir. Petrópolis: Vozes, 1987. - A verdade e as formas jurídicas. Rio de Janeiro: PUC/RJ e Nau editoras, 1996.

HABERMAS, Jürgen. Mudança estrutural na esfera pública. Rio de Janeiro: Tempo Brasileiro, 2003.

NAGEL, Thomas; MURPHY, Liam. O mito da propriedade privada. São Paulo: Martins Fontes, 2005.

NOZICK, Robert. Anarquia, estado e utopia. Rio de Janeiro: Jorge Zahar Editores, 1994.

RAWLS, John. Uma teoria da justiça. São Paulo: Martins Fontes, 1997.

UNGER, Roberto Mangabeira. Política - textos centrais. São Paulo: Boitempo; Santa Catarina: Argos, 2001. 